\title{
Correction to: Prevalence and determinants of low social support during pregnancy among Australian women: a community-based cross-sectional study
}

\author{
Asres Bedaso ${ }^{1,2^{*}} \mathbb{C}$, Jon Adams ${ }^{2}$, Wenbo Peng ${ }^{2}$ and David Sibbritt ${ }^{2}$
}

\section{Correction to: Reprod Health (2021) 18:158} https://doi.org/10.1186/s12978-021-01210-y

Following publication of the original article [1], the authors reported some variation between the descriptive section and the percentages presented in Table 1 for some variables.

The original article [1] has been updated.

\section{Author details}

${ }^{1}$ College of Medicine and Health Sciences, Faculty of Health, School of Nursing, Hawassa University, Hawassa, Ethiopia. ${ }^{2}$ Australian Centre for Public and Population Health Research, School of Public Health, Faculty of Health, University of Technology Sydney, Ultimo, NSW, Australia.

Published online: 21 September 2021

\begin{abstract}
Reference
1. Bedaso A, Adams J, Peng W, et al. Prevalence and determinants of low social support during pregnancy among Australian women: a community-based cross-sectional study. Reprod Health. 2021;18:158. https://doi. org/10.1186/s12978-021-01210-y.
\end{abstract}

\section{Publisher's Note}

Springer Nature remains neutral with regard to jurisdictional claims in published maps and institutional affiliations. to the material. If material is not included in the article's Creative Commons licence and your intended use is not permitted by statutory regulation or exceeds the permitted use, you will need to obtain permission directly from the copyright holder. To view a copy of this licence, visit http://creativecommons.org/licenses/by/4.0/. The Creative Commons Public Domain Dedication waiver (http://creativeco mmons.org/publicdomain/zero/1.0/) applies to the data made available in this article, unless otherwise stated in a credit line to the data. 